\title{
Splitting Tensile Strength of Ternary Blended Concrete Containing Phosphogypsum and Silica Fume
}

\author{
Leena V P \\ Department of civil Engineering \\ Musaliar College of Engineering and Technology, \\ Pathanamthitta, Kerala, India
}

\author{
Bismi M Buhari \\ Department of civil Engineering \\ Musaliar College of Engineering and Technology, \\ Pathanamthitta, Kerala, India
}

\author{
Subhalekshmi \\ Department of civil Engineering \\ Musaliar College of Engineering and Technology, \\ Pathanamthitta, Kerala, India
}

\begin{abstract}
Phosphogypsum is the second largest waste material produced in the World. It contained small quantities of silica, fluorine and phosphate as impurities. These impair the strength development of calcined products. Because of the reason phosphogypsum can be effectively used in cement replacement. $10 \%$ Silica fume and $5-15 \%$ of phopshogypsum by weight of cement are used for this investigation
\end{abstract}

Keywords - phosphogypsum; calcined product; silica fume

\section{INTRODUCTION}

Ordinary concrete has a single cementitious material i.e. cement. Binary blend of concrete includes cement as the binding material and a pozzolanic material being added. Ternary blended concrete marks the inclusion of two different pozzolanic materials to the concrete with cement acting as the primary binding material. Durability of concrete is increased by the reduction of Calcium Hydroxide content which causes Sulphate Attack. Fly ash from coal fired power plants and metakaolin are both important in modern concrete technology [2]. Enlarging the scope of material science to Supplementary Cementious Materials (SCM) viz., fly ash, slag, silica fume, rice husk ash and Metakaolin in the use of concrete, this led to the concept of blended cements and blended concretes. Thus impact during early hydration was reduction in generation of surplus $\mathrm{Ca}(\mathrm{OH}) 2$, control of heat of hydration and mitigation of continuous bleed channels. So, reorienting the mix design for improved performance of concrete with thrust on, (a) Controlling OPC content but increasing the total cementitious material, (b) Controlling water content, using chemical admixture, for improved workability, for offsetting slow hydration with SCM. Thus the impermability was achieved. In India, about 6 million tons of waste gypsum such as phosphogypsum, flourogypsum etc., are being generated annually [3]. Phosphogypsum refers to the gypsum formed as a by-product of processing phosphate ore into fertilizer with sulfuric acid.

\section{METHODOLOGY}

Phopshogypsum and silica fume was used as binding material along with cement. $10 \%$ silica fume is fixed for all mixes according to IS456-2000(clause-5.2.1.1) and IS 15388-2003 (code for silica fume specification)[10,11]. At first Control mix of M30 grade is prepared to get sufficient 28 day characteristic strength. Then different mixes are prepared by replacing cement with $10 \%$ silica fume and $0 \%, 5 \%, 7.5 \%$, $10 \%, 12.5 \%, 15 \%$ of phosphogypsum. Fresh properties of different mixes studied by slump test and compacting factor test. Then splitting tensile strength test is conducted for different mixes

\section{MATERIALS AND METHODS}

Materials used are cement, fine aggregate, coarse aggregate, silica fume and phosphogypsum. All materials are tested as per standard procedures to assess their engineering properties and the results were compared with those in relevant IS codes.

TABLE I. PROPERTIES OF CEMENT

\begin{tabular}{|c|c|}
\hline Grade & OPC 53 Grade \\
\hline Fineness & $5 \%$ \\
\hline Consistency & $35 \%$ \\
\hline In][itial setting time & 240 minutes \\
\hline /Specific gravity & 3.125 \\
\hline
\end{tabular}

TABLE II.

PROPERTIES OF FINE AGGREGATE

\begin{tabular}{|c|c|}
\hline Specific gravity & 2.69 \\
\hline Bulk density & $1.22 \mathrm{~kg} / /$ \\
\hline Percentage voids & $54.53 \%$ \\
\hline Water absorption & $1.50 \%$ \\
\hline Fineness modulus & 2.51 \\
\hline
\end{tabular}

TABLE III. PROPERTIES OF COARSE AGGREGATE 


\begin{tabular}{|c|c|}
\hline Specific gravity & 2.67 \\
\hline Bulk density & $1.32 \mathrm{~kg} / \mathrm{l}$ \\
\hline Percentage voids & $50.41 \%$ \\
\hline Water absorption & $0.80 \%$ \\
\hline Fineness modulus & 2.97 \\
\hline
\end{tabular}

TABLE IV

MIX PROPORTION

\begin{tabular}{|c|c|c|c|c|}
\hline \multirow{2}{*}{$\begin{array}{c}\text { Grade of } \\
\text { Concrete }\end{array}$} & cement & Fine aggregate & $\begin{array}{c}\text { Coarse } \\
\text { aggregate }\end{array}$ & $\begin{array}{c}\text { Water- } \\
\text { cement } \\
\text { ratio }\end{array}$ \\
\hline M30 & 1 & 2.426 & 3.154 & 0.45 \\
\hline
\end{tabular}

TABLE V.

QUANTITY OF MATERIALS USED

\begin{tabular}{|c|c|c|c|c|c|c|}
\hline $\begin{array}{c}\text { Mix } \\
\text { designation }\end{array}$ & $\begin{array}{c}\text { Cement } \\
\mathrm{Kg} / \mathrm{m}^{3}\end{array}$ & $\begin{array}{c}\text { Silica } \\
\text { Fume } \\
\mathrm{Kg} / \mathrm{m}^{3}\end{array}$ & $\begin{array}{c}\mathrm{PG} \\
\mathrm{Kg} / \mathrm{m}^{3}\end{array}$ & $\begin{array}{c}\text { Fine } \\
\text { aggregate } \\
\mathrm{Kg} / \mathrm{m}^{3}\end{array}$ & $\begin{array}{c}\text { Coarse } \\
\text { aggregate } \\
\mathrm{Kg} / \mathrm{m}^{3}\end{array}$ & $\begin{array}{c}\text { water } \\
\mathrm{Kg} / \mathrm{m}^{3}\end{array}$ \\
\hline M30 & 350.22 & 0.00 & 0.00 & 850 & 1104.70 & 176.19 \\
\hline PG0 & 315.00 & 30.58 & 0.00 & 850 & 1104.70 & 176.19 \\
\hline PG5 & 297.50 & 30.58 & 13.11 & 850 & 1104.70 & 176.19 \\
\hline PG7.5 & 288.75 & 30.58 & 19.66 & 850 & 1104.70 & 176.19 \\
\hline PG10 & 280.00 & 30.58 & 26.21 & 850 & 1104.70 & 176.19 \\
\hline PG12.5 & 271.25 & 30.58 & 32.76 & 850 & 1104.70 & 176.19 \\
\hline PG15 & 262.50 & 30.58 & 39.31 & 850 & 1104.70 & 176.19 \\
\hline
\end{tabular}

\section{SPLITTING TENSILE STRENGTH TEST}

The split tensile strength test is a well known indirect test used for determining the tensile strength of concrete. Test was carried out on concrete cylinder of size $150 \mathrm{~mm} \times 300 \mathrm{~mm}$ as per IS 5816:1999 specification. In split tensile strength test, concrete cylinder was placed with its axis horizontal, between the loading surface of a compression testing machine and the load was applied until the failure occurred due to a splitting in the plane, containing the vertical diameter of the specimen. In order to reduce the magnitude of high compression stress near the points of application of the load, narrow packing strips of plywood were placed between the specimen and loading plates of the testing machine. The split tensile strength was determined for various mixes after 28 day water curing. Figure 3.7 shows split tensile strength test on cylinder. The measured splitting tensile strength fc, of the specimen shall be calculated to the nearest $0.05 \mathrm{~N} / \mathrm{mm}^{2}$ using the following formula :

$$
\mathrm{fp}=2 \mathrm{p} / \pi \mathrm{ld}
$$

$\mathrm{P}=$ maximum load in $\mathrm{N}$ applied to the specimen.

$l=$ length of the specimen (in $\mathrm{mm}$ ), and

$\mathrm{d}=$ cross sectional dimension of the specimen (in $\mathrm{mm}$ ).

\section{TEST RESULTS}

\section{A. Control Mix}

In this study, replacement of cement by silica fume and phosphogypsum is done on M30 design mix. 7 and 28 day splitting tensile strength and flexural strength values of M30 is shown in table.
TABLE VI.

SPLITTING TENSILE STRENGTH VALUE OF M30

\begin{tabular}{|c|c|c|}
\hline & 7 Day & 28 Day \\
\hline $\begin{array}{c}\text { Splitting tensile } \\
\text { strength }\left(\mathrm{N} / \mathrm{mm}^{2}\right)\end{array}$ & 1.6 & 3.91 \\
\hline
\end{tabular}

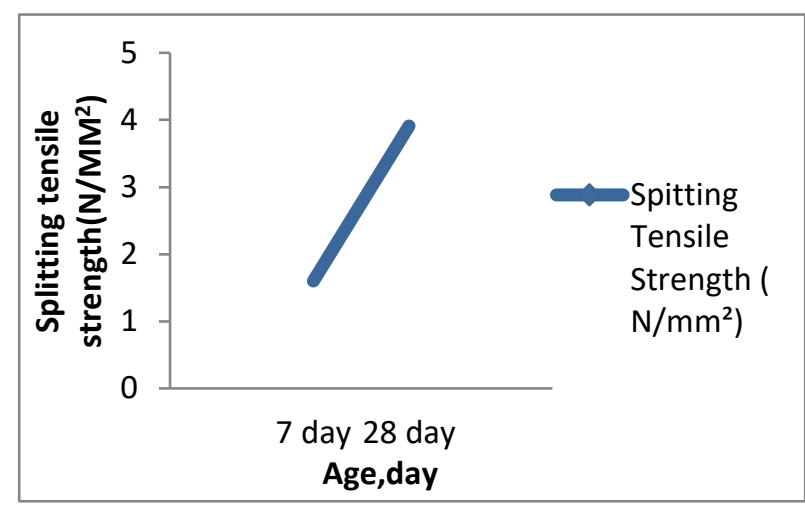

Fig. 1. Splitting tensile strength values of M30.

\section{B. Cement Replaced with $10 \%$ SF \& $0 \%$ PG (PGO)}

$10 \%$ cement in M30 mix is replaced with silica fume is selected as the first mix for study.

\section{TABLE VII. SPLITTING TENSILE STRENGTH VALUE OF PG0}

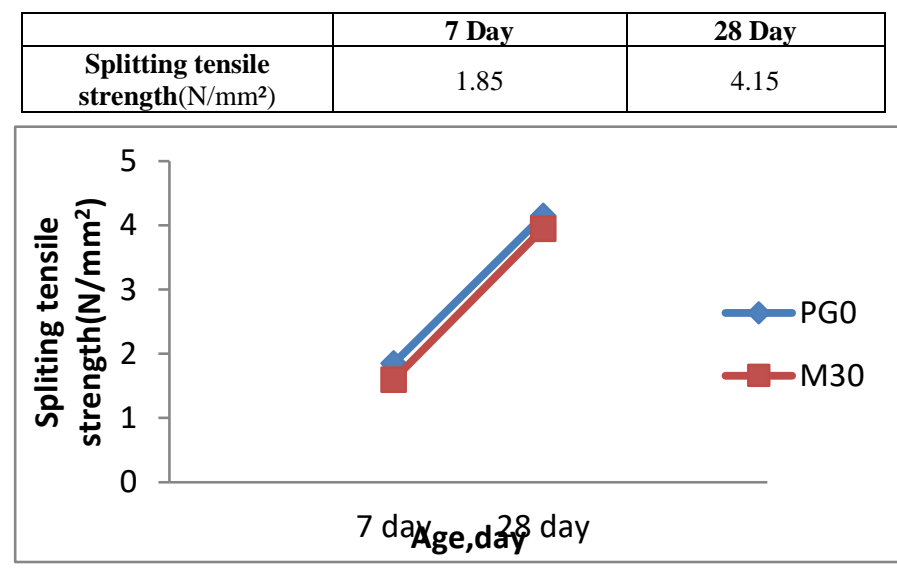

Fig. 2. Splitting tensile strength values of PG0

\section{Cement Replaced with $10 \%$ SF \& 5\% PG (PG5)}

$15 \%$ cement in M30 mix is replaced with $10 \%$ silica fume and $5 \%$ of phosphogypsum for study.

\section{TABLE VIII. SPLITTING TENSILE STRENGTH VALUE OF PG5}

\begin{tabular}{|c|c|c|}
\hline & 7 Day & 28 Day \\
\hline $\begin{array}{c}\text { Splitting tensile } \\
\text { strength }\left(\mathrm{N} / \mathrm{mm}^{2}\right)\end{array}$ & 2.15 & 4.2 \\
\hline
\end{tabular}

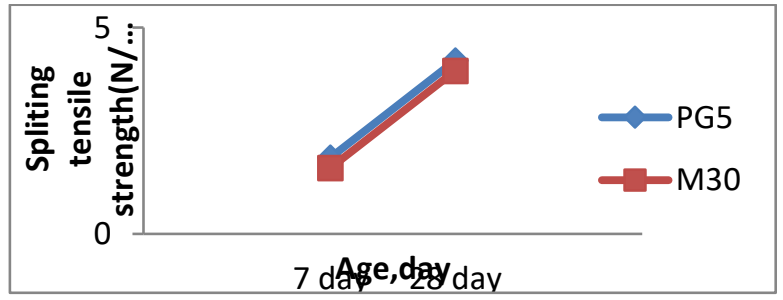

Fig. 3. Splitting tensile strength values of PG5 
D. Cement Replaced with $10 \%$ SF \& $7.5 \%$ PG (PG7.5

$17.5 \%$ cement in M30 mix is replaced with $10 \%$ silica fume and $7.5 \%$ of phosphogypsum for study.

TABLE IX. SPLITTING TENSILE STRENGTH VALUE OF PG7.5

\begin{tabular}{|c|c|c|}
\hline & 7 Day & 28 Day \\
\hline $\begin{array}{c}\text { Splitting tensile } \\
\text { strength }\left(\mathrm{N} / \mathrm{mm}^{2}\right)\end{array}$ & 2.1 & 4.29 \\
\hline
\end{tabular}

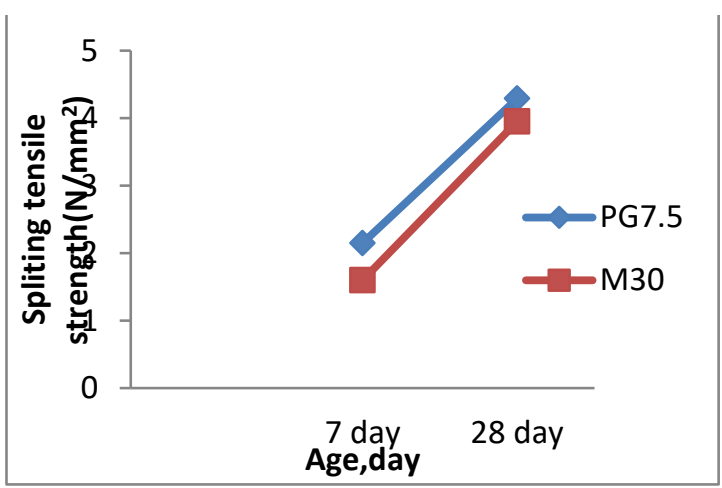

Fig. 4. Splitting tensile strength values of PG7.5

E. Cement Replaced with $10 \%$ SF \& $10 \%$ PG (PG10)

$20 \%$ cement in M30 mix is replaced with $10 \%$ silica fume and $10 \%$ of phosphogypsum for study.

TABLE X. SPLITTING TENSILE STRENGTH VALUE OF PG10

\begin{tabular}{|c|c|c|}
\hline & 7 Day & 28 Day \\
\hline $\begin{array}{c}\text { Splitting tensile } \\
\text { strength }\left(\mathrm{N} / \mathrm{mm}^{2}\right)\end{array}$ & 1.3 & 4.1 \\
\hline
\end{tabular}

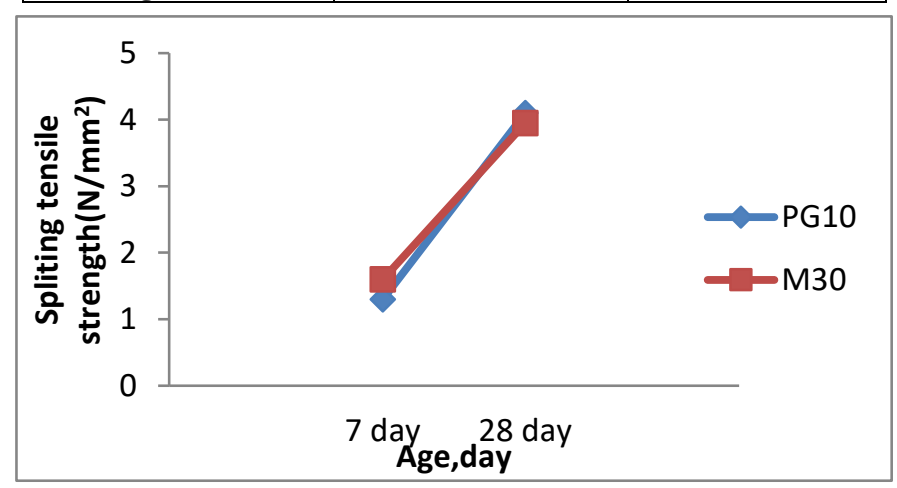

Fig. 5. Splitting tensile strength values of PG10

F. Cement Replaced with $12.5 \%$ SF \& $10 \%$ PG (PG 12.5)

$22.5 \%$ cement in M30 mix is replaced with $10 \%$ silica fume and $12.5 \%$ of phosphogypsum for study.

TABLE XI.

PLITTING TENSILE STRENGTH VALUE OF PG12.5

\begin{tabular}{|c|c|c|}
\hline & 7 Day & 28 Day \\
\hline $\begin{array}{c}\text { Splitting tensile } \\
\text { strength }\left(\mathrm{N} / \mathrm{mm}^{2}\right)\end{array}$ & 1.05 & 4.05 \\
\hline
\end{tabular}

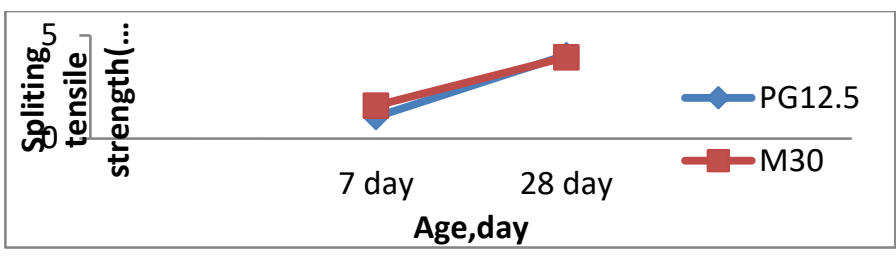

Fig. 6. Splitting tensile strength values of PG12.5

G. Cement Replaced with $15 \%$ SF \& $10 \%$ PG (PG 15)

$25 \%$ cement in M30 mix is replaced with $10 \%$ silica fume and $15 \%$ of phosphogypsum for study.

TABLE XII.

SPLITTING TENSILE STRENGTH VALUE OF PG15

\begin{tabular}{|c|c|c|}
\hline & 7 Day & 28 Day \\
\hline $\begin{array}{c}\text { Splitting tensile } \\
\text { strength }\left(\mathrm{N} / \mathrm{mm}^{2}\right)\end{array}$ & 1.00 & 3.75 \\
\hline
\end{tabular}

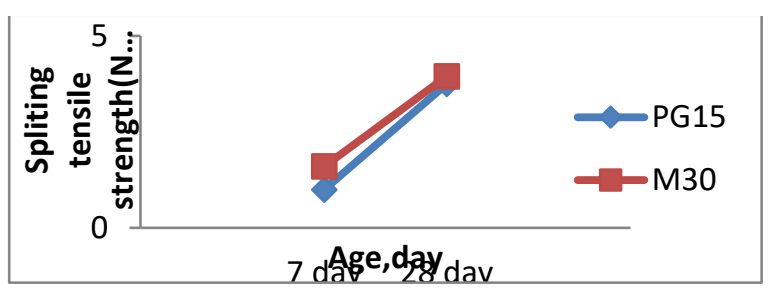

Fig. 7. Splitting tensile strength values of PG15

\section{H. Comparison of Result}

TABLE XIII. COMPARISON OF RESULTS

\begin{tabular}{|c|c|c|}
\hline \multirow{2}{*}{ Mix Designation } & \multicolumn{2}{|c|}{$\begin{array}{c}\text { Splitting tensile } \\
\text { strength(N/mm }{ }^{2} \text { ) }\end{array}$} \\
\cline { 2 - 3 } & 7 Day & 28 Day \\
\hline M30 & 1.60 & 3.90 \\
\hline PG0 & 1.85 & 4.15 \\
\hline PG5 & 2.15 & 4.20 \\
\hline PG7.5 & 2.10 & 4.30 \\
\hline PG10 & 1.30 & 4.10 \\
\hline PG12.5 & 1.05 & 4.05 \\
\hline PG15 & 1.00 & 3.75 \\
\hline
\end{tabular}

Figure shows the comparison of splitting tensile strength. 7 day and 28 day spitting tensile strength retain nearly constant ratio. 7 day strength is maximum at PG5 and 28 day strength is maximum at PG7.5. Above $7.5 \%$ phosphogypsum replacement along with $10 \%$ silica fume decreases the splitting tensile strength. 


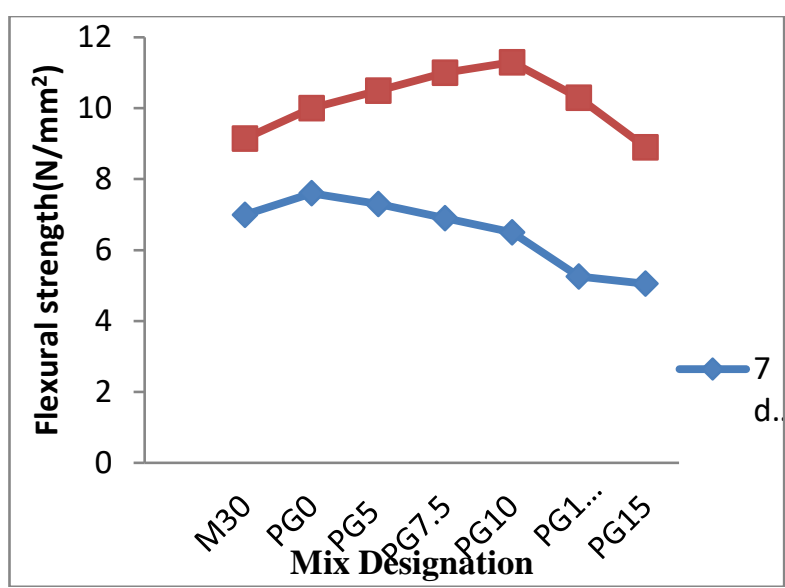

Fig. 8. Comparison of results

\section{CONCLUSION}

The present investigation had presented results of the experimental study to evaluate the suitability of utilizing phosphogypsum and silica fume as supplementary cementatious materials in ternary blended concrete in M30 concrete.

- The workability of ternary blended concrete containing silica fume and phosphogypsum decreased when percentage replacement increases. This is due to higher percentage of finer particles than 150 microns.

- Splitting tensile strength and flexural strength were improved on the addition of phosphogypsum along with $10 \%$ silica fume.

- Increasing amount of supplementary cementitious materials in concrete extent set time and slow strength development, leading to low early age strengths and delay in the rate of construction

\section{ACKNOWLEDGEMENT}

I would like to express my personal thanks to all the support given from the college and also the second author for her continuous encouragement.

\section{REFERENCES}

[1] S. Dhinakaran and R. Mercy Shanthi,"Experimental Investigation on Concrete with Phosphogypsum ",International Journal on Emerging Researches in Engineering Science and Technology - Volume 2 issue 3 March 2015 - ISSN - 23939184.

[2] Suchita R Saikhede, S. R. Satone, Department of Civil Engineering, RTMN University, Nagpur, INDIA," An Experimental Investigation of Partial Replacement of Cement by Various Percentage of Phosphogypsum And Flyash In Cement Concrete“, International Journal of Engineering Research and Applications Vol. 4, Issue 7( Version 4), July 2014, pp.37-40

[3] Khalid Mohammed Breesem and Faris Gorashi," Behavior of SelfCompacting Concrete Using Different Sludge and Waste Materials- A General Overview “, International Journal of Chemical, Environmental \& Biological Sciences (IJCEBS) Volume 2, Issue 3 (2014) ISSN 2320-4087 (Online).

[4] Dr. Vaishali. G. Ghorpade and Dr. Sudarsana Rao, H , "Deriving Mix Proportions For Different Grades Of Phosphogypsum Based Self Compacting Concrete" International Journal of Engineering Research and Applications (IJERA) ISSN: 2248-9622 www.ijera.com Vol. 3, Issue 3, May-Jun 2013, pp.467-473 .

[5] Dinesh W Gawatre ,"Advantages of Waste-Phosphogypsum in Concrete",IJSR - International Journal of Scientific Researchvolume : 2 ,Issue : 2 , Feb 2013,Issn No $2277-8179$.

[6] Mahesh A. Bagade and S. R. Satone ,"An experimental investigation of partial replacement of cement by various percentage of Phosphogypsum in cement concrete", International Journal of Engineering Research and Applications (IJERA) ISSN: 2248-9622, www.ijera.com Vol. 2, Issue 4, July-August 2012, pp.785-787.

[7] T. Siva Sankar Reddy and D. Rupesh Kumar," A Study on Strength Characteristics of Phosphogypsum Concrete", Asian Journal ff Civil Engineering (Building And Housing) Vol. 11, No. 4 (2010) Pages 411420 .

[8] S. S. Bhadauria, Rajiv Gandhi Proudyogiki Vishwavidyalya, Bhopal (M P.), India Rajesh B. Thakare, JSPM's B. N. College of Engineering, Pusad (M. S.), "Utilisation of Phosphogypsum In Cement Mortar And Concrete", 31st Conference on Our World In Concrete \& Structures: 16 17 August 2006, Singapore .

[9] R B Thakare, B N College of Engineering, India, K G Hiraskar, KIT's College of Engineering, India, O P Bhatia, Shri G S Institute of Technology and Science, "Utilisation of phosphogypsum in cement concrete for strength and economy" 26th Conference on Our World in Concrete \& Structures: 27 - 28 August 2001, Singapore. 